\title{
Endophytic fungi of marine algae and seagrasses: a novel source of chitin modifying enzymes
}

\author{
Venkatachalam $\mathrm{A}^{1}$, Govinda Rajulu $\mathrm{MB}^{1}$, Thirunavukkarasu $\mathbf{N}^{2}$ and \\ Suryanarayanan $\mathbf{T S}^{1^{*}}$ \\ ${ }^{1}$ Vivekananda Institute of Tropical Mycology (VINSTROM), Ramakrishna Mission Vidyapith, Chennai 600004, India \\ t_sury2002@yahoo.com* \\ ${ }^{2} P G$ \& Research Department of Botany, Ramakrishna Mission Vivekananda College, Chennai 600004, India
}

Venkatachalam A, Govinda Rajulu MB, Thirunavukkarasu N, Suryanarayanan TS 2015Endophytic fungi of marine algae and seagrasses: a novel source of chitin modifying enzymes. Mycosphere 6(3), 345-355, Doi 10.5943/mycosphere/6/3/10

\begin{abstract}
Endophytic fungi (which infect living tissues of plants and reside in them without causing any visible disease symptoms) were isolated from 19 seaweed and 10 seagrass species growing in Mandapam (Palk Bay, 9 $9^{\circ} 16^{\prime} \mathrm{N}, 7^{\circ} 7^{\prime} \mathrm{E}$ ), Keezhakarai (Palk Bay, 9 $9^{\circ} 3^{\prime} \mathrm{N}, 78^{\circ} 46^{\prime} \mathrm{E}$ ), Kodiyakkarai (Palk Strait, $10^{\circ} 16^{\prime} \mathrm{N}, 9^{\circ} 49^{\prime} \mathrm{E}$ ) and Kovalam (Bay of Bengal, $8^{\circ} 22^{\prime} \mathrm{N}, 76^{\circ} 59^{\prime} \mathrm{E}$ ) along the eastern coast of Tamilnadu state, southern India and screened for the production of chitinase and chitosanase enzymes. This study was done during July 2012- December 2012. Of the 117 fungi screened, $14 \%$ was positive for chitinase, $41 \%$ was positive for chitosanase acting on chitosan of $56 \%$ degree of acetylation, $66 \%$ was positive for chitosanase acting on chitosan of degree of acetylation $38 \%$ and $56 \%$ was positive for chitosanase acting on chitosan of degree of acetylation 1.6\%. Among the isolates, a Penicillium sp. and a Cladosporium sp. showed high chitinase activity. Presence of $\mathrm{NaCl}$ in the medium influenced the production and activity of chitinase and chitosanase. This study identifies for the first time endophytic fungi of marine plants as a novel source of chitin modifying enzymes which find use in food, cosmetics, agriculture and pharmaceutical industries.
\end{abstract}

Key words - chitinase - chitosanase - marine-derived fungi - marine angiosperms - seaweeds

\section{Introduction}

Chitin, a polymer of $\beta-1,4$ linked $\mathrm{N}$-acetylglucosamine, is an abundant but under-utilized natural resource obtained mostly from shells of marine crustaceans. Both chitin and chitosan, a partially deacetylated chitin derivative, are non-toxic, biodegradable and biocompatible and hence find use in food, cosmetics, agriculture and pharmaceutical applications (Dutta et al. 2004). Chitooligosaccharides are oligomers derived from chitin or chitosan with potential to be used as drugs, antibacterial agents, wound-healing chemicals and vectors in gene therapy (Aam et al. 2010, Park \& Kim 2010). The process of obtaining chitin and chitosan from the shells of crustaceans involves treatment with strong alkali; similarly, chitooligosaccharides are generated by acid hydrolysis of chitosans. Here, the use of chitin modifying enzymes such as chitinase and chitosanase to obtain functional chitin derivatives including biofunctional chitooligosaccharides 
appears to be a better option as it is environmentally friendly and would result in products with known characteristics such as molecular weight, molecular weight distribution, and pattern of Nacetylation (Aam et al. 2010). In this context, bacterial chitin modifying enzymes have received more attention than those of fungi (Kielak et al. 2013, Frederiksen et al. 2013). Fungal chitin modifying enzymes, apart from modulating their growth, branching, spore formation and spore germination (El Gueddari et al. 2002, Karlsson \& Stenlid 2008), play a major role in recycling nitrogen and carbon trapped in chitin (Kellner et al. 2010). Of the different ecological groups of fungi, endophytes appear to possess a repertoire of novel enzymes (Nagarajan et al. 2014, Thriunavukkarasu et al. 2011) including chitin modifying enzymes (Govinda Rajulu et al. 2011; Nagaraju et al. 2009). Endophytes are fungi which infect living tissues of plants and survive in them without producing any apparent disease symptoms. Although a few recent studies have shown that infection by endophytes increases the host plant's tolerance to abiotic (Vesterlund et al. 2011) and biotic (Rocha et al. 2011) stress and results in the up-regulation of many defense-related genes of the host plant (Mejía et al. 2014), many questions regarding endophyte biology remain unanswered (Suryanarayanan 2013). We screened in this study endophytes (which were marinederived fungi) isolated from marine algae and seagrasses for their chitin modifying enzymes. Fungi occurring in marine ecosystems are broadly classified as true or obligate marine fungi and marine-derived fungi; the former grow and sporulate only in marine environment while the latter are terrestrial fungi but also occur in marine environments (Kohlmeyer \& Kohlmeyer 1979).

\section{Materials \& Methods}

\section{Isolation of endophytes from seaweeds and seagrasses}

Endophytes isolated from 19 seaweed and 10 seagrass species were screened in this study. The seaweeds included seven brown algae [Lobophora variegata (LVA), Padina tetrastromatica (PTE), Sargassum ilicifolium (SIL), S. wightii (SWI), Sargassum sp. (SAR), Stoechospermum marginatum (SMA) and Turbinaria sp. (TUR)], seven green algae [Caulerpa racemosa (CRA), $C$. scalpelliformis (CSC), C. sertularioides (CSE), Chaetomorpha sp. (CHA), Halimeda macroloba (HMA), Ulva fasciata (UFA) and U. lactuca (ULA)], and five red algae [Gracilaria edulis (GED), Grateloupia lithophila (GLI), Halymenia sp. (HAY), Jania adharens (JAD) and Portieria hornemanii (PHO)]. The seagrasses included Cymodocea serrulata (CYS), Halodule beaudettei (HAB) , H. uninervis (HAU), Halodule sp.1 (HAL), Syringodium sp. (SYR), belonging to the family Cymodoceaceae and Enhalus acoroides (ENA), Halophila ovalis (HAO), Thalassia sp. 1(TH1), Thallasia sp. 2 (TH2) and Thalassia sp. 3 (TH3) belonging to the family Hydrocharitaceae. Seaweeds and seagrasses were collected from Mandapam (Palk Bay, $9^{\circ} 16^{\prime} \mathrm{N}$,

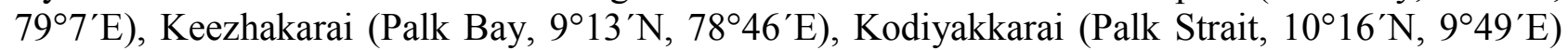
and Kovalam (Bay of Bengal, $8^{\circ} 22^{\prime} \mathrm{N}, 76^{\circ} 59^{\prime} \mathrm{E}$ ) along the eastern coast of Tamil nadu state, southern India.

Fresh algal thalli and healthy, mature seagrasses having undamaged leaves and growing in shallow seawater were collected and brought to the laboratory in sterile polythene bags and processed within $24 \mathrm{~h}$. The surface sterilization protocol for isolating endophytes was as follows. The seaweeds were washed in running tap water and cut into segments of approximately $0.5 \mathrm{~cm}^{2}$; these tissue segments were dipped in $70 \%$ ethanol for $5 \mathrm{~s}$ followed by immersion in sterile distilled water for $10 \mathrm{~s}$ (modified after Zhang et al. 2009). Seagrasses were washed in running tap water and tissue segments $\left(0.5 \mathrm{~cm}^{2}\right)$ were cut from the mid portion of mature leaves and rhizomes and surface sterilized as follows. Segments were rinsed in $70 \%$ ethanol for $5 \mathrm{~s}$, immersed in $4 \%$ sodium hypochlorite for $60 \mathrm{~s}$ and finally rinsed in sterile distilled water (Devarajan et al. 2002).

One hundred sterilized segments from each seaweed or seagrass were plated on potato dextrose agar medium amended with an antibiotic (chloramphenicol $150 \mathrm{mg}^{-1}$ ) in Petri dishes and incubated in a light chamber for four weeks at $26^{\circ} \mathrm{C}$; the light regimen was $12 \mathrm{~h}$ of light followed by $12 \mathrm{~h}$ of darkness (Suryanarayanan 1992). The Petri dishes were observed periodically, and the 
fungi that grew out from the tissues were isolated and identified based on spore morphology. The identity of five of the isolates was further corroborated by 5.8S rRNA analysis - 542- Chaetomium spirochaete (GenBank Accession No. JN209921), 548 - Chaetomium globosum (JF826006), 568 Trichoderma harzianum (KC330218), 580 - Fusarium oxysporum (KC254033), 590 - Alternaria brassicae (JX984695) [Kaushik et al. 2014].

\section{Preparation of chitinase and chitosanase from fungal culture filtrates}

An endophyte was grown in Potato Dextrose medium (Potato $200 \mathrm{~g}$, Dextrose $20 \mathrm{~g}$, distilled water $1000 \mathrm{ml}, \mathrm{pH}$ 6) for 5 days as static culture at $26^{\circ} \mathrm{C}$ and the mycelium was removed by filtering through Whatman No. 1 filter paper. One hundred $\mathrm{ml}$ of the culture filtrate was dialyzed for $15 \mathrm{~h}$ against distilled water. The dialyzed culture filtrate was lyophilized and used as crude enzyme source.

\section{Dot blot assay and visualization of enzyme activity}

A composite gel consisting of stacks of glycol chitin, chitosans of $56 \%, 38 \%$ or $1.6 \%$ degree of acetylation was layered as follows (Govinda Rajulu et al. 2011).

A gel was prepared by mixing a solution of $1 \mathrm{ml}$ of $30 \%$ Acrylamide/Bisacrylamide, $0.1 \mathrm{ml}$ substrate (1\% glycol chitin), $1.9 \mathrm{ml}$ of $50 \mathrm{mM}$ sodium acetate buffer (pH 5.5), $0.003 \mathrm{ml}$ of $100 \%$ tetraethylmethylenediamide (TEMED) and $0.003 \mathrm{ml}$ of $40 \%$ ammonium persulphate, poured in a gel cassette and allowed to polymerize. A few drops of butanol was added to the top of the solidifying gel to help polymerization. After $20 \mathrm{~min}$, the butanol was decanted and the gel was topped with a solution of $1 \mathrm{ml}$ of $30 \%$ Acrylamide/Bis acrylamide, $0.3 \mathrm{ml}$ substrate $(0.1 \%$ chitosan $56 \%$ Degree of Acetylation, $1.7 \mathrm{ml}$ of sodium acetate buffer ( $\mathrm{pH} \mathrm{5.5),} 0.003 \mathrm{ml}$ of 100\% TEMED, $0.003 \mathrm{ml}$ of $40 \%$ ammonium persulphate. The surface of this gel was layered with a few drops of butanol to facilitate polymerization. After $20 \mathrm{~min}$, the butanol was removed and this process was repeated with $(0.1 \%$ chitosan degree of acetylation $38 \%$ or $0.1 \%$ chitosan degree of acetylation $1.6 \%)$. Thus a compound gel consisting of chitin (100\% degree of acetylation), and chitosans of $56 \%$ degree of acetylation $38 \%$ degree of acetylation or $1.6 \%$ degree of acetylation was obtained.

$5 \mathrm{mg}$ of the lyophilized culture filtrate of each endophyte isolate (enzyme source) was mixed in $1 \mathrm{ml}$ of $50 \mathrm{mM}$ sodium acetate buffer ( $\mathrm{pH} \mathrm{5.2)}$ and centrifuged at $14000 \mathrm{rpm}$ for $5 \mathrm{~min}$ $\left(20{ }^{\circ} \mathrm{C}\right) .10 \mu \mathrm{l}$ of the supernatant was loaded on the gel and incubated at $37{ }^{\circ} \mathrm{C}$ for $24 \mathrm{~h}$; gels were stained with $0.1 \%$ calcofluor white for $5 \mathrm{~min}$ and washed with distilled water for $1 \mathrm{~h}$ and observed under UV transilluminator to detect zones of darkness which indicated enzyme activity. A $50 \mathrm{mM}$ Sodium acetate buffer, $\mathrm{pH} 5.2,(10 \mu \mathrm{l})$ spotted on the gel served as control.

\section{Effect of salt on chitin modifying enzymes}

Four representative isolates which were positive for all the chitin substrates screened isolates [Aspergillus sp. (507), Humicola (509), Sterile form (515) and Penicillium sp. (645)] were selected and cultured in PD medium or PD medium amended with $0,0.3$ or $0.6 \mathrm{M} \mathrm{NaCl}$ and their culture filtrate was screened by dot blot assay for chitinase and chitosanase acting on chitosan of degree of acetylation $1.6 \%$ as mentioned above.

\section{Spectrophotometric assay of chitinase (Wirth \& Wolf 1990)}

A reaction mixture consisting of $0.6 \mathrm{ml}$ of $0.1 \mathrm{M}$ sodium acetate buffer ( $\mathrm{pH} 5.2), 0.2 \mathrm{ml}$ of CM-chitin-RBV (Remazol Brilliant Violet-dye labelled chitin, Löwe Biochemica, Germany), and $0.02 \mathrm{ml}$ of enzyme preparation was made. The blank tube contained all these except the enzyme which was replaced by $0.02 \mathrm{ml}$ of buffer. The reaction mixture was mixed well and incubated at 37 ${ }^{\circ} \mathrm{C}$ for 30 min allowing the substrate to be digested. The reaction was terminated by adding $0.2 \mathrm{ml}$ of $2 \mathrm{~N} \mathrm{HCl}$, incubated in $0{ }^{\circ} \mathrm{C}$ for $10 \mathrm{~min}$, centrifuged at $14000 \mathrm{rpm}$ for $5 \mathrm{~min}$ and the supernatant used. The absorbance of the dye labelled $\mathrm{N}$-acetylglucosamine monomers and/or oligomers released from the violet dye labelled chitin was estimated at $550 \mathrm{~nm}$. 


\section{Results}

A total of 117 endophyte isolates (73 isolated from seaweeds and 44 from seagrasses) were screened for chitin modifying enzymes using glycol chitin (for chitinase) and chitosans with different degree of acetylations (DA) (for chitosanase) as substrates (Table 1). Aspergillus flavus (625), A. nidulans (560), Aspergillus sp. (507), Aureobasidium pullulans (585), Chaetomium sp. (680), Cladosporium sp. (624), Humicola sp. (509), and Penicillium spp. (552, 645, 642) produced enzymes which acted on chitin and all the three chitosan substrates tried.

Table 1 Chitinase and chitosanases enzyme activity of marine derived endophytic fungi (dot blot assay).

\begin{tabular}{|c|c|c|c|c|c|c|}
\hline \multirow[b]{2}{*}{ Fungus } & \multirow[b]{2}{*}{ Isolate } & \multirow[b]{2}{*}{ Host code } & \multirow[b]{2}{*}{ Glycol chitin } & \multicolumn{3}{|c|}{ Chitosans } \\
\hline & & & & $\begin{array}{c}\text { DA } \\
56 \%\end{array}$ & $\begin{array}{c}\text { DA } \\
\mathbf{3 8} \%\end{array}$ & $\begin{array}{c}\text { DA } \\
1.6 \%\end{array}$ \\
\hline Alternaria brassicae & 590 & TUR & - & - & ++ & - \\
\hline Alternaria sp. & 603 & SAR & - & - & ++ & ++ \\
\hline Alternaria sp. & 572 & SWI & - & - & - & ++ \\
\hline Alternaria sp. & 626 & SMA & - & - & - & - \\
\hline Alternaria sp. & 592 & TUR & - & - & ++ & ++ \\
\hline Alternaria sp. & 590 & TUR & - & - & ++ & - \\
\hline Aphanocladium sp. & 508 & TH1 & - & - & - & - \\
\hline Aspergillus flavus & 625 & TH1 & + & ++ & +++ & +++ \\
\hline Aspergillus sp. & 591 & TUR & - & +++ & +++ & +++ \\
\hline Aspergillus sp. & 597 & TUR & - & - & +++ & +++ \\
\hline Aspergillus sp. & 545 & ULA & - & + & ++ & +++ \\
\hline Aspergillus sp. & 524 & CRA & - & - & - & - \\
\hline Aspergillus sp. & 533 & $\mathrm{CSC}$ & - & + & ++ & - \\
\hline Aspergillus sp. & 525 & $\mathrm{CSE}$ & - & - & - & - \\
\hline Aspergillus sp. & 551 & HMA & - & ++ & +++ & +++ \\
\hline Aspergillus sp. & 600 & SAR & - & + & ++ & - \\
\hline Aspergillus sp. & 569 & SWI & - & - & - & + \\
\hline Aspergillus sp. & 570 & SWI & - & +++ & +++ & - \\
\hline Aspergillus sp. & 636 & ENA & - & ++ & +++ & ++ \\
\hline Aspergillus sp. & 637 & ENA & - & ++ & +++ & + \\
\hline Aspergillus sp. & 507 & TH1 & + & + & ++ & ++ \\
\hline Aspergillus sp. & 643 & CYS & + & + & - & + \\
\hline A. janus & 581 & SWI & - & +++ & +++ & ++ \\
\hline A. nidulans & 541 & PHO & - & ++ & ++ & - \\
\hline A. nidulans & 567 & SWI & - & +++ & +++ & - \\
\hline A. nidulans & 560 & HAY & + & +++ & + & + \\
\hline A. niger & 523 & CRA & - & - & - & - \\
\hline A. niger & 531 & $\mathrm{CSC}$ & - & - & - & - \\
\hline A. niger & 544 & ULA & - & - & - & + \\
\hline A. niger & 526 & CSE & - & - & - & - \\
\hline A. terreus & 532 & $\mathrm{CSC}$ & - & - & ++ & - \\
\hline A. terreus & 539 & GED & - & - & ++ & +++ \\
\hline A. terreus & 550 & HMA & - & ++ & +++ & - \\
\hline A. terreus & 598 & SAR & - & - & ++ & +++ \\
\hline A. terreus & 537 & SIL & - & - & ++ & +++ \\
\hline A. terreus & 611 & TUR & - & + & +++ & +++ \\
\hline A. terreus & 615 & UFA & - & ++ & + & +++ \\
\hline A. terreus & 543 & ULA & - & ++ & ++ & ++ \\
\hline A. terreus & 644 & CYS & - & - & ++ & - \\
\hline A. terreus & 639 & HAB & - & ++ & +++ & ++ \\
\hline A. terreus & 640 & SYR & - & ++ & +++ & ++ \\
\hline A. terreus & 641 & SYR & + & +++ & +++ & - \\
\hline A. terreus & 635 & ENA & - & - & - & +++ \\
\hline Aureobasidium pullulans & 585 & TH1 & + & + & + & - \\
\hline Chaetomium globosum & 548 & ULA & - & - & +++ & + \\
\hline Chaetomium spirochaete & 542 & GED & - & + & ++ & +++ \\
\hline
\end{tabular}




\begin{tabular}{|c|c|c|c|c|c|c|}
\hline \multirow[b]{2}{*}{ Fungus } & \multirow[b]{2}{*}{ Isolate } & \multirow[b]{2}{*}{ Host code } & \multirow[b]{2}{*}{ Glycol chitin } & \multicolumn{3}{|c|}{ Chitosans } \\
\hline & & & & $\begin{array}{c}\text { DA } \\
56 \% \\
\end{array}$ & $\begin{array}{c}\text { DA } \\
38 \% \\
\end{array}$ & $\begin{array}{c}\text { DA } \\
1.6 \% \\
\end{array}$ \\
\hline Chaetomium sp. & 559 & HAY & - & - & - & - \\
\hline Chaetomium sp. & 558 & PTE & - & + & - & - \\
\hline Chaetomium sp. & 576 & SMA & - & +++ & +++ & - \\
\hline Chaetomium sp. & 680 & TH3 & ++ & + & ++ & + \\
\hline Cladosporium sp. & 575 & GLI & - & - & +++ & +++ \\
\hline Cladosporium sp. & 564 & $\mathrm{PHO}$ & - & - & - & ++ \\
\hline Cladosporium sp. & 579 & SWI & - & - & - & - \\
\hline Cladosporium sp. & 547 & ULA & - & - & + & + \\
\hline Cladosporium sp. & 512 & $\mathrm{HAO}$ & + & - & + & - \\
\hline Cladosporium sp. & 624 & TH1 & + & + & ++ & ++ \\
\hline Cladosporium sp. & 520 & CRA & - & +++ & +++ & +++ \\
\hline Cladosporium sp. & 601 & SAR & - & - & ++ & - \\
\hline Cladosporium sp. & 505 & TH1 & - & - & - & - \\
\hline Cladosporium sp. & 506 & TH1 & - & - & - & - \\
\hline Colletotrichum sp. & 513 & $\mathrm{HAO}$ & - & - & - & - \\
\hline Curvularia lunata & 608 & SAR & - & - & - & - \\
\hline Curvularia sp. & 535 & CSC & - & - & - & - \\
\hline Curvularia sp. & 566 & SWI & - & - & + & +++ \\
\hline Curvularia sp. & 577 & SWI & - & - & - & + \\
\hline Curvularia sp. & 593 & TUR & - & - & ++ & + \\
\hline Curvularia sp. & 638 & ENA & - & - & + & - \\
\hline Curvularia sp. & 582 & TH1 & - & - & - & - \\
\hline Curvularia tuberculata & 606 & TUR & - & - & - & + \\
\hline C. tuberculata & 516 & SYR & - & - & - & - \\
\hline C. tuberculata & 503 & TH1 & - & + & +++ & ++ \\
\hline Drechslera papendorfii & 589 & TUR & - & - & - & - \\
\hline Drechslera sp. & 610 & TUR & - & ++ & +++ & - \\
\hline Drechslera sp. & 583 & TH1 & - & - & - & +++ \\
\hline Fusarium oxysporum & 580 & SWI & - & +++ & +++ & +++ \\
\hline Fusarium sp. & 595 & TUR & - & - & +++ & - \\
\hline Fusarium sp. & 623 & TH1 & - & - & - & - \\
\hline Gonatophragmium mori & 622 & TH1 & - & - & + & +++ \\
\hline Humicola sp. & 509 & $\mathrm{TH} 2$ & + & ++ & ++ & +++ \\
\hline Memnoniella sp. & 647 & CYS & - & - & ++ & ++ \\
\hline Nigrospora sp. & 573 & GLI & - & - & - & ++ \\
\hline Nigrospora sp. & 538 & JAD & - & - & - & - \\
\hline Nigrospora sp. & 594 & TUR & - & +++ & +++ & + \\
\hline Nigrospora sp. & 627 & UFA & - & - & ++ & - \\
\hline Nigrospora sp. & 546 & ULA & - & - & - & ++ \\
\hline Nigrospora sp. & 621 & HAU & - & - & + & - \\
\hline Nigrospora sp. & 646 & CYS & - & - & + & - \\
\hline Nigrospora sp. & 685 & CYS & - & + & ++ & - \\
\hline Nodulisporium sp. & 684 & SYR & - & - & + & - \\
\hline Nodulisporium sp. & 679 & TH3 & - & ++ & ++ & ++ \\
\hline Paecilomyces sp. & 534 & $\mathrm{CSC}$ & - & - & - & - \\
\hline Paecilomyces sp. & 584 & TH1 & - & + & - & ++ \\
\hline Paecilomyces sp. & 681 & TH1 & - & - & +++ & +++ \\
\hline Penicillium sp. & 527 & CSE & - & +++ & +++ & +++ \\
\hline Penicillium sp. & 563 & $\mathrm{PHO}$ & - & - & - & - \\
\hline Penicillium sp. & 511 & $\mathrm{HAO}$ & - & - & - & - \\
\hline Penicillium sp. & 521 & CRA & - & +++ & +++ & +++ \\
\hline Penicillium sp. & 536 & $\mathrm{CSC}$ & +++ & +++ & ++ & - \\
\hline Penicillium sp. & 552 & HMA & + & +++ & +++ & +++ \\
\hline Penicillium sp. & 645 & CYS & + & + & ++ & +++ \\
\hline Penicillium sp. & 642 & HAB & +++ & +++ & +++ & +++ \\
\hline Penicillium sp. & 504 & TH1 & - & + & +++ & +++ \\
\hline Pestalotiopsis sp. & 574 & SWI & - & - & - & + \\
\hline Phoma sp. & 605 & SAR & - & - & + & ++ \\
\hline Phomopsis sp. & 562 & $\mathrm{PHO}$ & - & - & - & - \\
\hline
\end{tabular}




\begin{tabular}{|c|c|c|c|c|c|c|}
\hline \multirow[b]{2}{*}{ Fungus } & \multirow[b]{2}{*}{ Isolate } & \multirow[b]{2}{*}{ Host code } & \multirow[b]{2}{*}{ Glycol chitin } & \multicolumn{3}{|c|}{ Chitosans } \\
\hline & & & & $\begin{array}{c}\text { DA } \\
56 \% \\
\end{array}$ & $\begin{array}{c}\text { DA } \\
38 \% \\
\end{array}$ & $\begin{array}{c}\text { DA } \\
1.6 \% \\
\end{array}$ \\
\hline Pithomyces sp. & 604 & SAR & - & - & + & - \\
\hline Pithomyces sp. & 682 & HAL & +++ & - & ++ & ++ \\
\hline Sterile form & 515 & $\mathrm{HAO}$ & + & +++ & +++ & +++ \\
\hline Sterile form & 530 & CRA & - & - & - & - \\
\hline Sterile form & 565 & $\mathrm{PHO}$ & - & - & - & ++ \\
\hline Sterile form & 614 & ULA & - & - & +++ & ++ \\
\hline Sterile form & 619 & CHA & - & - & ++ & - \\
\hline Sterile form & 561 & LVA & - & - & - & - \\
\hline Sterile form & 686 & CYS & - & - & + & +++ \\
\hline Sterile form & 687 & CYS & - & + & +++ & ++ \\
\hline Torulomyces sp. & 683 & SYR & - & +++ & +++ & + \\
\hline Trichoderma harzianum & 568 & SWI & - & - & +++ & - \\
\hline Xylariaceous form & 678 & TH3 & - & ++ & ++ & ++ \\
\hline
\end{tabular}

- = No activity, $+=$ Low activity, $++=$ Medium activity, $+++=$ High activity

\section{Chitinase}

Of the 117 endophyte isolates screened by dot blot assay, 16 isolates (14\%) were positive for chitinase enzyme (Table 1, Figs. 1-2); these included Aspergillus spp., Aureobasidium pullulans, Chaetomium sp., Cladosporium sp., Humicola sp. and Penicillium spp. These isolates were assayed spectrophtometrically for chitinase. Of these, a Penicillium sp. (isolate 645) endophytic in the seagrass $C$. serrulata and a Cladosporium sp. (isolate 512) isolated from the seagrass $H$. ovalis showed high activity (Fig. 3). Humicola sp. (509) and sterile form (515) which produced chitinase in normal medium failed to elaborate this enzyme in the presence of $\mathrm{NaCl}$ (Table 2); Aspergillus sp. (507) produced chitinase in normal and $0.3 \mathrm{M} \mathrm{NaCl}$ medium but not in $0.6 \mathrm{M} \mathrm{NaCl}$ medium. Penicillium sp. (645) elaborated chitinase in medium with $0,0.3$ and $0.6 \mathrm{M}$ $\mathrm{NaCl}$ (Table 2).

Table 2 Chitinase and chitosanases enzyme activity of marine derived fungi isolated from Seagrasses with different molarity(M) of $\mathrm{NaCl}$ amended medium by dot blot method.

\begin{tabular}{|c|c|c|c|c|c|c|c|c|}
\hline \multirow[b]{2}{*}{ Isolate } & \multirow[b]{2}{*}{ Host } & \multirow[b]{2}{*}{ Fungus } & \multicolumn{3}{|c|}{ Glycol chitin } & \multicolumn{3}{|c|}{ Chitosan DA $1.6 \%$} \\
\hline & & & $\mathbf{0} \mathbf{M}$ & $0.3 \mathrm{M}$ & $0.6 \mathrm{M}$ & $\mathbf{0} \mathbf{M}$ & $0.3 \mathrm{M}$ & $0.6 \mathrm{M}$ \\
\hline 507 & Thalassia sp. 1 & Aspergillus sp. & + & + & - & ++ & ++ & +++ \\
\hline 509 & Thalassia sp. 2 & Humicola sp. & + & - & - & +++ & - & - \\
\hline 515 & Halophila ovalis & Sterile form & + & - & - & +++ & ++ & ++ \\
\hline 645 & Cymodocea serrulata & Penicillium sp. & + & + & + & +++ & ++ & - \\
\hline
\end{tabular}

$-=$ No activity, $+=$ Low activity, $++=$ Medium activity,$+++=$ High activity

\section{Chitosanase}

Forty-eight isolates (41\% of the 117 isolates screened) including Aspergillus spp., Aureobasidium pullulans, Chaetomium spp., Cladosporium spp., Curvularia tuberculata, Drechslera sp., Fusarium oxysporum, Humicola sp., Nigrospora spp., Nodulisporium sp., Paecilomyces sp., Penicillium spp., Torulomyces sp. and xylariaceous form were positive for chitosanase acting on chitosan degree of acetylation 56\%. With chitosan degree of acetylation $38 \%$ as substrate, Alternaria spp., Aspergillus spp., Aureobasidium pullulans, Chaetomium spp., Cladosporium spp., Curvularia spp., Drechslera sp., Fusarium spp., Gonatophragmium mori, Humicola sp., Memnoniella sp., Nigrospora spp., Nodulisporium spp., Paecilomyces sp., Penicillium spp., Phoma sp., Pithomyces sp., Tourlomyces sp., Trichoderma harzianum and Xylariaceous form (77 isolates representing 66\%) were positive for the enzyme. With chitosan degree of acetylation $1.6 \%$ as substrate, Alternaria spp., Aspergillus spp., Chaetomium spp., Cladosporium spp., Curvularia spp., Drechslera sp., Fusarium oxysporum, Gonatophragmium 


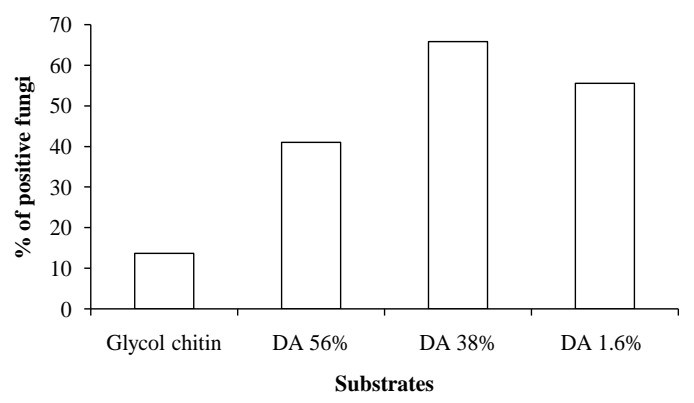

Fig. 1 - Percentage of marine derived fungal endophyte isolates from seaweeds and seagrasses positive for chitin modifying enzymes (dot blot method). Total number of isolates tested $=117$, DA $=$ Degree of acetylation

mori, Humicola sp., Memnoniella sp., Nigrospora spp., Nodulisporium sp., Paecilomyes spp., Penicillium spp., Pestalotiopsis sp., Phoma sp., Pithomyces sp., Torulomyces sp. and Xylariaceous form (65 isolates representing 56\%) were positive (Figs. 1-2 \& Table 1). More isolates of Aspergillus and Penicillium produced chitosanases acting on chitosans with different $\%$ of degree of acetylation (Table 1). Chitosanase activity of Humicola sp. (509) was absent when the fungus was cultured in salt amended (Table 2); in the case of sterile form (515) and Penicillium sp. (645), chitosanase activity reduced with the presence of salt in the medium. Interestingly, in the case of Aspergillus sp. (507), chitosanase activity was stronger (producing darker spots on dot blot gels) with higher salt concentration in the medium (Table 2).

\section{Discussion}

Many fungi including several species of Aspergillus (Narayanan et al. 2013), Beauveria bassiana, Trichoderma harzianum, Lecanicillium lecanii, Metarhizium anisopliae, Fusarium spp. (Duo-chuan 2006, Matsumoto 2006) produce chitinase enzymes. Fungi produce 25 different types of chitinases (Seidl 2008); the products of chitinases are useful in control of tumours and microbes, wound healing, drug delivery and wastewater treatment (Aoyagi et al. 2007, Dai et al. 2009, Da Sacco \& Masotti 2010, Nam et al. 2010). Furthermore, chitooligosaccharides have been reported to exhibit antimicrobial, hypo-cholesterolemic, immune-stimulating, and anti- cancer activities (Aam et al. 2010). Although there has been an increased interest on microbial chitinases for this reason, various aspects regarding their expression and regulation are still unknown (Seidl 2008). One option to overcome this bottleneck in realizing fully the technological potential of chitinase is to explore as many different ecological groups of fungi for their chitin modifying enzymes (Govinda Rajulu et al. 2011, Hartl et al. 2012). Govinda Rajulu et al. (2011) reported for the first time that endophytes of terrestrial plants are a good source of chitin modifying enzymes. In the present study, we show that endophytes of marine angiosperm and seaweeds could be a novel source of chitin modifying enzymes. We observed that species of Aspergillus which are known to dominate the endophytes assemblages of both seagrasses (Venkatachalam et al. 2015) and seaweeds (Suryanarayanan et al. 2010) could elaborate different chitin modifying enzymes when compared to the other genera of endophytes isolated (Table 1). The same species of endophyte harboured by different plant host differ in their chitin modifying enzymes profile indicating the 

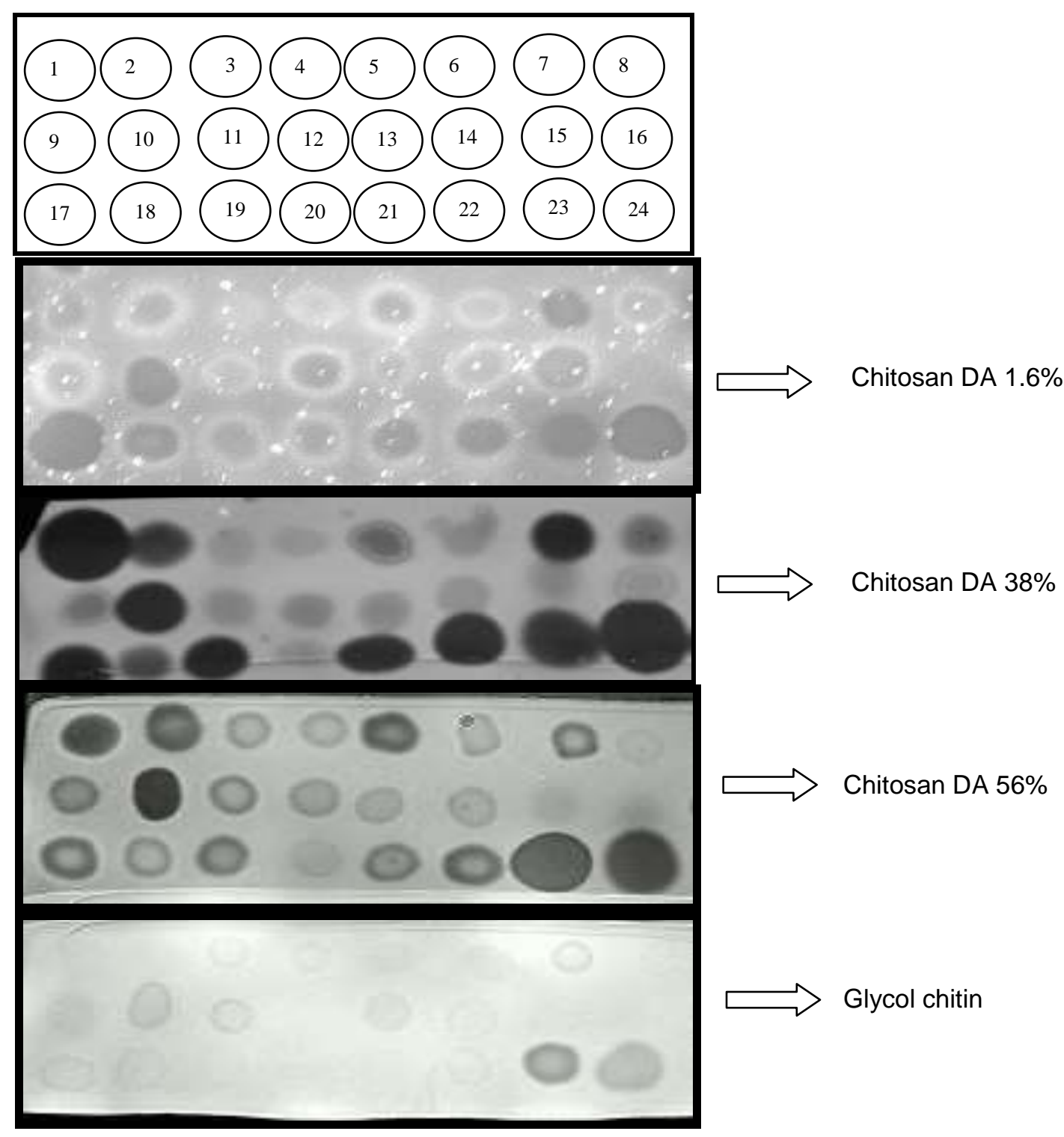

Fig. 2 - Dot blot assay for chitinase and chitosanase activity of marine-derived endophytes from seagrasses

\begin{tabular}{|c|c|c|c|}
\hline Dot no. & Isolate & Dot no. & Isolate \\
\hline 1. & Curvularia tuberculata (503) & 13. & Aureobasidium pullulans (585) \\
\hline 2. & Penicillium sp. (504) & 14. & Nigrospora sp. (621) \\
\hline 3. & Cladosporium sp. (505) & 15. & Gonatophragmium mori (622) \\
\hline 4. & Cladosporium sp. (506) & 16. & Fusarium sp. (623) \\
\hline 5. & Aspergillus sp. (507) & 17. & Aspergillus flavus (625) \\
\hline 6. & Aphanocladium sp. (508) & 18. & Aspergillus sp. (636) \\
\hline 7. & Humicola sp. (509) & 19. & Aspergillus sp. (637) \\
\hline 8. & Penicillium sp. (511) & 20. & Curvularia sp. (638) \\
\hline 9. & Colletotrichum sp. (513) & 21. & Aspergillus terreus (639) \\
\hline 10. & Sterile form (515) & 22. & Aspergillus terreus (640) \\
\hline 11. & Curvularia tuberculata (516) & 23. & Aspergillus terreus (641) \\
\hline 12. & Paecilomyces sp. (584) & 24. & Penicillium sp. (642) \\
\hline
\end{tabular}




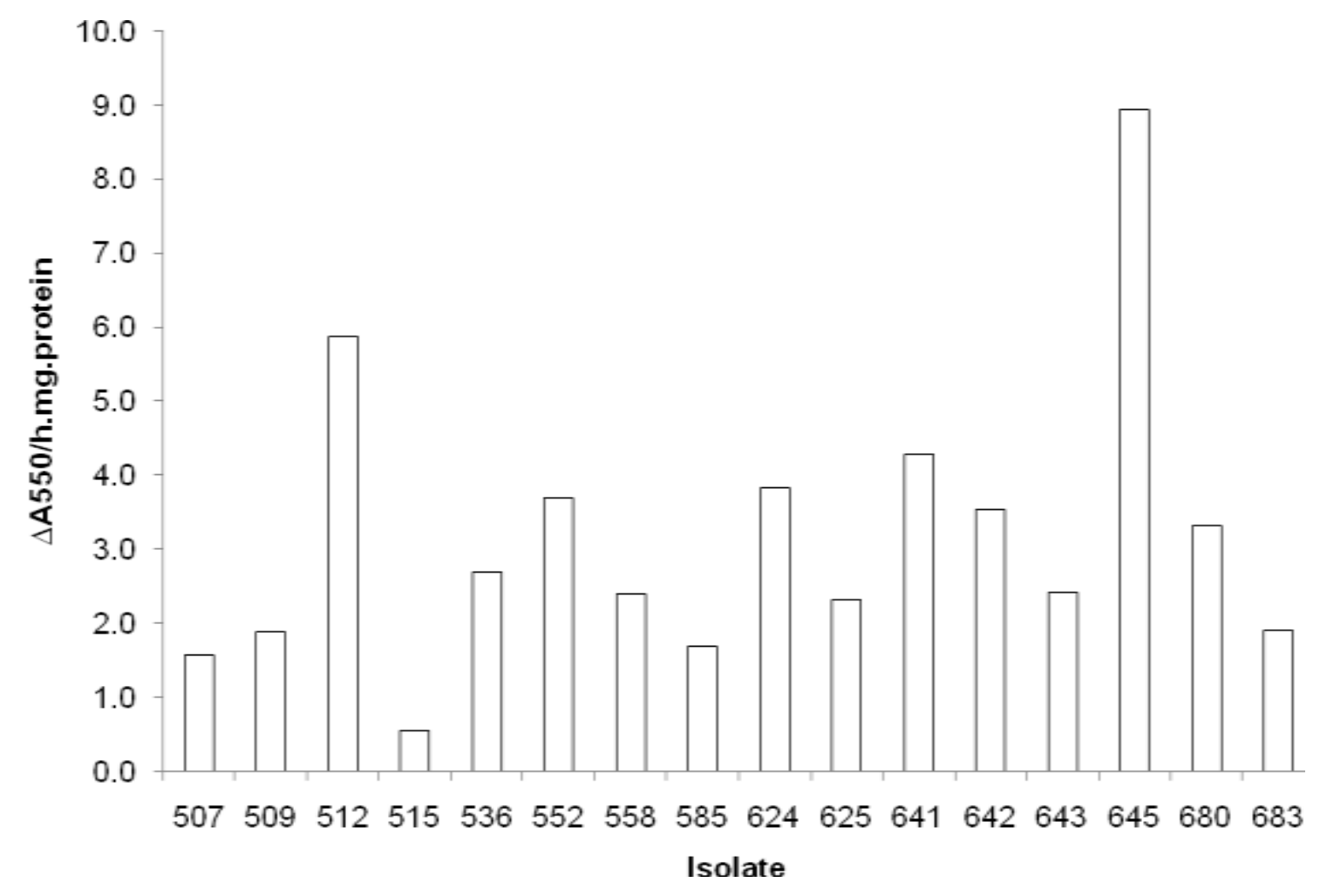

Fig. 3 - Spectrophotometric assay of chitinases of marine derived fungi isolated from seaweeds and seagrasses. Refer isolate code Table 1

high diversity of these enzymes in these fungi. For instance, A. terreus and C. tuberculata isolated from different hosts (or even from the same host) showed different degrees of activity on chitin/chitosans (Table 1). This result is similar to that obtained by Govinda Rajulu et al. (2011) for endophytes of terrestrial plants and substantiates their conclusion that endophytes need to be explored vigorously for their chitin modifying enzymes. The observation that many endophytes of marine plants elaborate different chitosanases (Fig. 1 \& Table 1) is of significance since more detailed studies are likely to identify a variety of this enzyme from these fungi. It is important to identify a variety of microbial chitin modifying enzymes since unlike production of chitooligosaccharides form chitosan by acid hydrolysis, enzyme action on chitosan would result in production of defined chitooligosaccharides with known fraction of $\mathrm{N}$-acetylated residues, molecular weight distribution, and pattern of $\mathrm{N}$-acetylation - a highly desirable attribute for the many pharmaceutical applications of chitooligosaccharides (Aam et al. 2010). It appears that action of chitin modifying enzymes of marine-derived endophytes is influenced by salt. This preliminary observation need to be explored in detail to understand the role of salt in the induction and action of chitin modifying enzymes of this ecological group of fungi. It is pertinent to mention here that the presence of salt induces chitinase in plants (Hong \& Hwang 2002) and alters the composition of cell wall destructuring enzymes produced by a mangrove fungus (Arfi et al. 2013). The need for studies on fungal endophytes of seaweeds for technological exploitation has been stressed recently (Suryanarayanan \& Johnson 2014). Focused studies on chitin modifying enzymes of marine-derived endophytes to understand their regulation and expression (homologous and heterologous) and features such as substrate-binding properties and functional overlaps would help in choosing appropriate enzymes for various technological applications. 


\section{Acknowledgements}

Our thanks are due to the Secretary, Ramakrishna Mission Vidyapith, Mylapore, Chennai for providing facilities. NT thanks the Department of Science and Technology, Government of India for funding the SERB project (SB/EMEQ-005/2013).

\section{References}

Aam BB, Heggset EB, Norberg AL, Sørlie M, Vårum KM, Eijsink VGH. 2010 - Production of chitooligosaccharides and their potential applications in medicine. Marine Drugs 8, 14821517.

Aoyagi S, Onishi H, Machida Y. 2007 - Novel chitosan wound dressing loaded with minocycline for the treatment of severe burn wounds. International Journal of Pharmaceutics 330, 138145.

Arfi Y, Chevret D, Henrissat B, Berrin J-G, Levasseur A, Record E. 2013 - Characterization of salt-adapted secreted lignocellulolytic enzymes from the mangrove fungus Pestalotiopsis sp. Nature Communications 4, 1810.

Da Sacco L, Masotti A. 2010 - Chitin and chitosan as multipurpose natural polymers for groundwater arsenic removal and $\mathrm{As}_{2} \mathrm{O}_{3}$ delivery in tumor therapy. Marine Drugs 8, 15181525 .

Dai T, Tegos GP, Burkatovskaya M, Castano AP, Hamblin MR. 2009 - Chitosan acetate bandage as a topical antimicrobial dressing for infected burns. Antimicrobial Agents and Chemotheraphy 53, 393-400.

Devarajan PT, Suryanarayanan TS, Geetha V. 2002 - Endophytic fungi associated with the tropical seagrass Halophila ovalis (Hydrocharitaceae). Indian Journal of Marine Sciences 31, 73-74.

Duo-Chuan L. 2006 - Review of fungal chitinases. Mycopathologia 161, 345-360.

Dutta PK, Dutta J, Tripathi VS. 2004 - Chitin and chitosan: chemistry, properties and applications. Journal of Scientific and Industrial Research 63, 20-31.

El Gueddari N, Rauchhaus U, Moerschbacher BM, Deising HB. 2002 - Developmentally regulated conversion of surface-exposed chitin to chitosan in cell walls of plant pathogenic fungi. New Phytologist 156, 103-112.

Frederiksen RF, Paspaliari DK, Larsen T, Storgaard BG, Larsen MH, Ingmer H, Palcic MM, Leisner JJ. 2013 - Bacterial chitinases and chitin-binding proteins as virulence factors. Microbiology 159, 833-847.

Govinda Rajulu MB, Thirunavukkarasu N, Suryanarayanan TS, Ravishankar JP, El Gueddari NE, Moerschbacher BM. 2011 - Chitinolytic enzymes from endophytic fungi. Fungal Diversity 47, 43-53.

Hartl L, Simone Zach S, Seidl-Seiboth V. 2012 - Fungal chitinases: diversity, mechanistic properties and biotechnological potential. Applied Microbiology and Biotechnology 93, 533543.

Hong JK, Hwang BK. 2002 - Induction by pathogen, salt and drought of a basic class II chitinase mRNA and its in situ localization in pepper (Capsicum annuum). Physiologia Plantarum 114, 549-558.

Karlsson M, Stenlid J. 2008 - Comparative evolutionary histories of the fungal chitinase gene family reveal non-random size expansions and contractions due to adaptive natural selection. Evolutionary Bioinformatics Online 4, 47-60.

Kaushik NK, Murali TS, Sahal D, Suryanarayanan TS. 2014 - A search for antiplasmodial metabolites among fungal endophytes of terrestrial and marine plants of southern India. Acta Parasitologica 59, 745-757.

Kellner H, Zak DR, Vandenbol M. 2010 - Fungi unearthed: Transcripts encoding lignocellulolytic and chitinolytic enzymes in forest soil. PLoS ONE 5(6), e10971. 
Kielak AM, Cretoiu MS, Semenov AV, Sørensen SJ, van Elsas JD. 2013 - Bacterial chitinolytic communities respond to chitin and $\mathrm{pH}$ alteration in soil. Applied and Environmental Microbiology 79, 263-272.

Kohlmeyer J, Kohlmeyer E. 1979 - Marine mycology: The higher fungi. Academic Press, New York.

Matsumoto KS. 2006 - Fungal chitinase. In: Guevara-González RG, Torres-Pacheco I (eds) Advances in agricultural and food biotechnology, CABI Publishing, India, pp 289-304.

Mejía LC, Herre EA, Sparks JP, Winter K, Garcia MN, Van Bael SA, Stitt J, Shi Z, Zhang Y, Gultinan MJ, Maximova SN. 2014 - Pervasive effects of a dominant foliar endophytic fungus on host genetic and phenotypic expression in a tropical tree. Frontiers in Microbiology. doi:10.3389/fmicb.2014.00479

Nagarajan A, Thirunavukkarasu N, Suryanarayanan TS, Gummadi SN. 2014 - Screening and isolation of novel glutaminase free l-asparaginase from fungal endophytes. Research Journal of Microbiology 9, 163-176.

Nagaraju D, Govinda Rajulu MB, El Gueddari NE, Suryanarayanan TS, Moerschbacher BM. 2009 - Identification and characterization of chitinolytic enzymes from endophytic fungi. Sugars in Norwich, RSC Carbohydrate Group Meeting, London, UK.

Nam T, Park S, Lee SY, Park K, Choi K, Song IC, Han MH, Leary JJ, Yuk SA, Kwon IC, Kim K, Jeong SY. 2010 - Tumor targeting chitosan nanoparticles for dual-modality optical/MR cancer imaging. Bioconjugate Chemistry 21, 578-582.

Narayanan K, Chopade N, Vasanth Raj P, Subrahmanyam VM, Venkata Rao J. 2013 - Fungal chitinase production and its application in biowaste management. Journal of Scientific and Industrial Research 72, 393-399.

Park B, Kim M-M. 2010 - Applications of chitin and its derivatives in biological medicine. International Journal of Molecular Sciences 11, 5152-5164.

Rocha ACS, Garcia D, Uetanabaro APT, Carneiro RTO, Araújo IS, Mattos CRR, Góes-Neto A. 2011 - Foliar endophytic fungi from Hevea brasiliensis and their antagonism on Microcyclus ulei. Fungal Diversity 47, 75-84.

Seidl V. 2008 - Chitinases of filamentous fungi: a large group of diverse proteins with multiple physiological functions. Fungal Biology Reviews 22, 36-42.

Suryanarayanan TS. 1992 - Light-incubation: a neglected procedure in mycology. Mycologist 6, 144.

Suryanarayanan TS. 2013 - Endophyte research: going beyond isolation and metabolite documentation. Fungal Ecology 6, 561-568.

Suryanarayanan TS, Johnson JA. 2014 - Fungal endosymbionts of macroalgae: need for enquiries into diversity and technological potential. Oceanography $2,119$.

Suryanarayanan TS, Venkatachalam A, Thirunavukkarasu N, Ravishankar JP, Doble M, Geetha V. 2010 - Internal mycobiota of marine macroalgae from the Tamilnadu coast: distribution, diversity and biotechnological potential. Botanica Marina 53, 457-468.

Thirunavukkarasu N, Suryanarayanan TS, Murali TS, Ravishankar JP, Gummadi SN. 2011 - Lasparaginase from marine derived fungal endophytes of seaweeds. Mycosphere 2, 147-155.

Venkatachalam A, Thirunavukkarasu N, Suryanarayanan TS. 2015 - Distribution and diversity of endophytes in seagrasses. Fungal Ecology 13, 60-65.

Vesterlund S-R, Helander M, Faeth S, Hyvönen T, Saikkonen K. 2011 - Environmental conditions and host plant origin override endophyte effects on invertebrate communities. Fungal Diversity 47, 109-118.

Wirth SJ, Wolf GA. 1990 - Dye-labelled substrates for the assay and detection of chitinase and lysozyme activity. Journal of Microbiological Methods 12, 197-205.

Zhang Y, Mu J, Feng Y, Kang Y, Zhang J, Gu P, Wang Y, Ma L, Zhu Y. 2009 - Broadspectrum antimicrobial epiphytic and endophytic fungi from marine organisms: Isolation, bioassay and taxonomy. Marine Drugs 7, 97-112. 